\title{
PASSIVE AND ACTIVE PROTECTION AGAINST THE DEVELOP- MENT OF PATHOLOGICAL CHANGES IN PIGLETS INFECTED WITH BORDETELLA BRONCHISEPTICA
}

\author{
F. ŠIŠÁK, M. GOIŠ, F. KUKSA \\ Veterinary Research Institute, 62132 Brno
}

Received March 9, 1979

\begin{abstract}
Šišák F., M. Goiš, F. Kuksa: Passive and Active Protection Against the Development of Pathological Changes in Piglets Infected with Bordetella bronchiseptica. Acta vet. Brno, 48, 1979: 85-94.

Active and passive immunization of piglets against Bordetella bronchiseptica restricted the development of gross changes in the nasal turbinates and lung after intranasal or contact infection. Gnotobiotic piglets were used to test the effect of specific hyperimmune serum against $B$. bronchiseptica in relation to the concentration of intranasally administered organisms: infection with $10^{5}$ colony-forming units (CFU) of B. bronchiseptica/ml did not produce turbinate atrophy in any of 6 serum-treated piglets, but did so in 6 of 7 controls; infection with $10^{7} \mathrm{CFU} / \mathrm{ml}$ produced turbinate atrophy in 2 and lung lesions in 1 of 5 serum-treated piglets as against turbinate atrophy and lung lesions in 4 and 2 animals, respectively, out of 4 controls; infection with $10^{\circ} \mathrm{CFU} / \mathrm{ml}$ produced turbinate atrophy in 3 and lung lesions in 4 of 5 serum-treated piglets as against atrophy and lung lesions in 5 and 4 animals, respectively, out of 5 controls.

Intraperitoneal vaccination of piglets from a herd with minimum morbidity with two doses of inactivated $B$. bronchiseptica failed to yield convincing results: turbinate atrophy was found in 4 out of 6 vaccinated animals and in all 6 controls. After double vaccination of 4 conventional piglets into the nasal submucosa, slight turbinate atrophy was found in 1 experimental animal as against 2 out of 4 controls. After double subcutaneous vaccination of 6 conventional piglets, all experimental animals had normal turbinates where as 3 of 6 controls showed turbinate atrophy.

The numbers of $B$. bronchiseptica in the turbinate mucosa and lung were generally higher in the controls than in actively or passively immunized piglets. Piglets immunized actively by any of the three routes employed produced specific agglutinating antibodies.
\end{abstract}

Atrophic rhinitis, immunization, inactivated vaccine, specific antiserum.

Bordetella bronchiseptica is one of the most common initiators of the processes resulting in turbinate atrophy and other changes in the nasal cavities of pigs. Mild forms of turbinate atrophy after experimental infection with $B$. bronchiseptica alone have been reported by a number of investigators (Ross et al. 1967; Harris and Switzer 1968; Shimizu 1971; Kemeny 1972; Logomarsino et al. 1974; Goiš et al. 1974; Brassinne et al. 1976; Edington et al. 1976; Tornoe and Nielsen 1976).

The earlier view that Pasteurella multocida has an aetiological relation to atrophic rhinitis (AR) (Gwatkin et al. 1953) has recently been shared by a number of other writers (Dirks et al. 1973; $\mathrm{Nielsen}$ et al. 1976; de Jong et al. 1976), although some investigators failed to produce experimentally pathomorphological changes reminiscent of AR (Harris and Switzer 1968; Nakaga wa et al. 1974; Goiš et al. 1975).

The present study demonstrates the possibility of passive and active protection against $B$. bronchiseptica infection under experimental conditions. 


\section{Materials and Methods}

\section{Experimental Animals}

The animals used were gnotobiotic piglets, reared in incubators, piglets from a minimum-disease herd and piglets from conventional dams. All were negative for $B$. bronchiseptica and $P$. multocida on microbiological examination by means of nasal swabs before the start of the experiments. Some groups of animals were examined in this way several times during the experiments.

\section{Preparation of Bordetella bronchiseptica bacterin}

$\mathrm{Br}$ 1, a low-passage strain of Bordetella bronchiseptica isolated from the nasal cavity of a piglet with AR, was inoculated into brain heart infusion (OXOID, CM 225) and the cultures were agitated on a shaker at 110 oscillations per min. for 24 hours at $37^{\circ} \mathrm{C}$. T'he resultant growth was concentrated by adding to it a culture of the same strain that was grown on meat-peptone agar with 1 per cent glucose and washed from the agar surface with saline. After the concentrated culture was checked for purity and the number of organisms was determined [this was invariably higher than $10^{10}$ colony-forming units (CFU) per ml], the organisms were inactivated with formalin to a final concentration of $1: 500$ and checked for inactivity 24 hours later. The bacterin thus prepared was frozen twice and stored at $+4^{\circ} \mathrm{C}$ until use.

\section{Preparation of Hyperimmune Sera for Passive Immunization}

Hysterectomy-derived and colostrum-deprived piglets from a minimum-disease herd, approximately $60 \mathrm{~kg}$ in weight; were immunized with inactivated antigen of either B. bronchiseptica or Mycoplasma hyorhinis strain S 218 administered in incomplete Freund's adjuvant in seven to nine 10-ml doses; the first two doses were injected subcutaneously (s. c.) behind the ears and the next five to seven doses were given intravenously (i. v.) at weekly intervals. The animals were killed one week after administration of the last dose. The agglutination titre of $B$. bronchiseptica antiserum was $1: 1280(0.1 \mathrm{ml})$ and the titre of metabolism-inhibiting antibodies of $M$. hyorhinis antiserum was $1: 640(0.1 \mathrm{ml})$.

\section{Active Immunization of Piglets}

The following three types of immunization were employed:

(1) Intraperitoneal (i. p.) immunization with two 1-ml doses of bacterin

(2) Immunization by injection of two $0.5-\mathrm{ml}$ doses of bacterin into the nasal submucosa approximately 1.0 to $1.5 \mathrm{~cm}$ deep, the injection being made from the medial side of the rims of the nasal cavities

Table 1

Effect of specific hyperimmune serum against Bordetella bronchiseptica in gnotobiotic pigilts infected with Bordetella bronchiseptica*

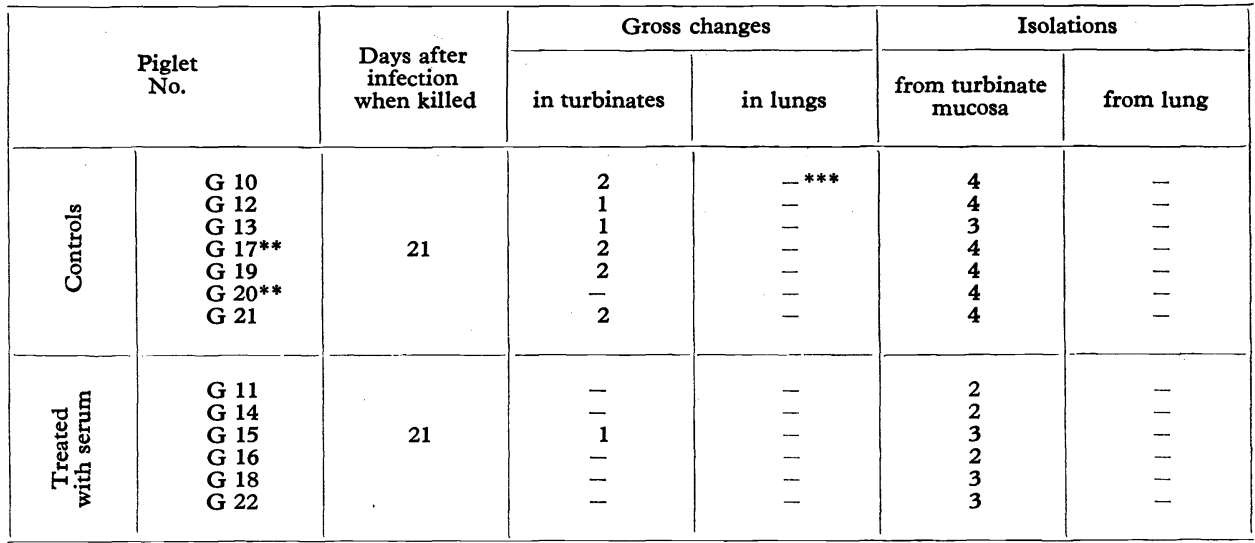

* Infecting inoculum titre of $5.0 \times 10^{5} \mathrm{CFU} / \mathrm{ml}$

** Contact infection

*** Negative findings 
(3) Immunization by s. c. injection of two $2-\mathrm{ml}$ doses of vaccine mixed in equal volume with Freund's incomplete adjuvant, with the first dose injected in the axillary region and the second in the inguinal region 7 days later.

Other relevant data are given in Tables $5-7$.

Passive Immunization of piglets

Three groups of piglets were given antiserum against $B$. bronchiseptica $\mathbf{i}$. p. in two doses (3 and $5 \mathrm{ml}$ ) on the $3 \mathrm{rd}$ and 5 th days after birth. Another group received mixed antiserum against $B$. bronchiseptica and $M$. hyorhinis (āa) in two i. p. doses of $5 \mathrm{ml}$ on the 3 rd and 5 th days after birth.

\section{Infection of piglets}

The infecting strain of $B$. bronchiseptica was propagated in the same way as in the preparation of bacterin. Experimental piglets were infected with a 24-hour live culture by instilling $0.5 \mathrm{ml}$ of the culture, diluted to the appropriate concentration, into both nostrils of each piglet in the supine position. After the piglets were infected, each inoculum was tested for the quantity of organisms; their numbers are given in Results.

Actively immunized piglets were challenged after the second dose at times specified in the tables. Passively immunized piglets were challenged at 6 days of age - the day following the second dose of antiserum. Details of combined B. bronchiseptica and M. hyorhinis challenge are given in Table 4.

Control piglets of each group were infected in the same way as the experimental animals.

\section{Necropsy and Microbiological Examination}

Piglets were killed at intervals specified in individual tables and examined for gross changes in the nasal turbinates, septum and mucosa after cross-sectioning the nasal cavity at the level of the mouth corners. Macroscopic turbinate atrophy was graded as follows: 1, slight; 2, moderate; 3, marked. Lung lesions were evaluated after opening the thoracic cavity by the following criteria: 1 , slight lesions in one lobe; 2 , slight lesions in more than one lobe; 3 , extensive lesions.

After gross examination of the turbinates, both parts of the nasal cavity remaining in the head portion after sectioning were swabbed with a sterile pad for microbiological examination. Excisions taken from the lung lesions were also examined by culture. The numbers of $B$. bronchiseptica were determined by evaluating their growth on the Mac Conkey medium using the following scoring system: 1 , solitary colonies; 2 , light growth; 3 , heavy growth; 4 , massive growth. The concentration of $M$. hyorhinis was determined by titration in a mycoplasma growth fluid medium and the results were expressed in colour-changing units (Purcell et al. 1966).

$B$. bronchiseptica agglutinins the sera of vaccinated and control piglets were demonstrated by the rapid agglutination method as described by Kemeny (1973).

\section{Results}

Passive Immunization. of Piglets Against B. bronchiseptica alone and in Combination with $M$. hyorhinis

The effect of hyperimmune serum against $B$. bronchiseptica was investigated in relation to various concentrations of challenge doses of $B$. bronchiseptica in three groups of gnotobiotic piglets kept in incubators throughout the experiment. Its protective effect was most pronounced in piglets infected with the lowest dose of $B$. bronchiseptica employed, i. e. $5.0 \times 10^{5} \mathrm{CFU} / \mathrm{ml}$. Of 7 control piglets in this group, 6 showed turbinate atrophy varying from slight to moderate (grade 1 to 2), whereas all the 6 experimental piglets passively immunized with the hyperimmune serum exhibited no gross changes and had, for the most part, lower counts of organisms in the nasal cavities than the controls (Table 1). The lungs of both experimental and control piglets of this group were negative by gross as well as cultural examination.

In the group of piglets infected with $B$. bronchiseptica at a rate of $3.0 \times 10^{7}$ $\mathrm{CFU} / \mathrm{ml}$ the 4 controls all had marked (grade 3 ) turbinate atrophy and two of them had also marked lesions in the lung. Of the five passively immunized piglets, 2 showed changes in the turbinates and one also in the lung. Microbiological 
Table 2

Effect of specific hyperimmune serum against Bordetella bronchiseptica in gnotobiotic piglets infected with Bordetella bronchiseptica *

\begin{tabular}{|c|c|c|c|c|c|c|}
\hline \multirow{2}{*}{\multicolumn{2}{|c|}{$\begin{array}{l}\text { Piglet } \\
\text { No. }\end{array}$}} & \multirow{2}{*}{$\begin{array}{l}\text { Days after } \\
\text { infection } \\
\text { when killed }\end{array}$} & \multicolumn{2}{|c|}{ Gross changes } & \multicolumn{2}{|c|}{ Isolations } \\
\hline & & & in turbinates & in lungs & from turbinate & from lung \\
\hline 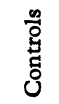 & $\begin{array}{l}\text { G } 01 \\
\text { G } 02 \\
\text { G } 03 \\
\text { G } 04\end{array}$ & 20 & $\begin{array}{l}3 \\
3 \\
3 \\
3\end{array}$ & $\frac{-}{3}$ & $\begin{array}{l}4 \\
3 \\
3 \\
4\end{array}$ & $\begin{array}{l}3 \\
4 \\
3 \\
4\end{array}$ \\
\hline 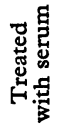 & $\begin{array}{l}\text { G } 05 \\
\text { G } 06 \\
\text { G 07** } \\
\text { G 08** } \\
\text { G } 09\end{array}$ & 20 & $\begin{array}{r}- \\
\overline{3} \\
2 \\
-\end{array}$ & $\begin{array}{l}- \\
- \\
- \\
-\end{array}$ & $\begin{array}{l}4 \\
3 \\
3 \\
3 \\
2\end{array}$ & $\begin{array}{l}- \\
- \\
- \\
-\end{array}$ \\
\hline
\end{tabular}

* Infecting inoculum titre of $3.0 \times 10^{7} \mathrm{CFU} / \mathrm{ml}$

** Very small piglets weighing less than $1 \mathrm{~kg}$ at birth

Table 3

Effect of specific hyperimmune serum against Bordetella bronchiseptica in gnotobiotic piglets infected with Bordetella bronchiseptica

\begin{tabular}{|c|c|c|c|c|c|c|}
\hline \multirow{2}{*}{\multicolumn{2}{|c|}{$\begin{array}{l}\text { Piglet } \\
\text { No. }\end{array}$}} & \multirow{2}{*}{$\begin{array}{l}\text { Days after } \\
\text { infection } \\
\text { when killed }\end{array}$} & \multicolumn{2}{|c|}{ Gross changes } & \multicolumn{2}{|c|}{ Isolations } \\
\hline & & & in turbingtes & קחמוl & from turbinate & from lung \\
\hline 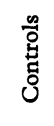 & $\begin{array}{ll}\mathrm{G} & 0 \\
\mathrm{G} & 1 \\
\mathrm{G} & 2 \\
\mathrm{G} & 3 \\
\mathrm{G} & 4\end{array}$ & 22 & $\begin{array}{l}3 \\
3 \\
3 \\
3 \\
3\end{array}$ & $\begin{array}{l}3 \\
3 \\
-3 \\
3\end{array}$ & $\begin{array}{l}\mathbf{4} \\
\mathbf{4} \\
\mathbf{3} \\
\mathbf{4} \\
\mathbf{4}\end{array}$ & $\begin{array}{l}4 \\
4 \\
1 \\
4 \\
4\end{array}$ \\
\hline 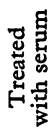 & $\begin{array}{l}\text { G } \\
\text { G } 6 \\
\text { G } 7 \\
\text { G } 8 \\
\text { G } 9\end{array}$ & 22 & $\begin{array}{l}- \\
- \\
3 \\
3 \\
3\end{array}$ & $\begin{array}{l}- \\
- \\
3 \\
3 \\
1\end{array}$ & $\begin{array}{l}3 \\
3 \\
3 \\
3 \\
3\end{array}$ & $\begin{array}{l}2 \\
2 \\
3 \\
3 \\
3\end{array}$ \\
\hline
\end{tabular}

* Infecting inoculum titre of $5.0 \times 10^{9} \mathrm{CFU} / \mathrm{ml}$

Table 4

Effect of bivalent specific hyperimmune serum in conventional piglets infected with Mycoplasma hyorhinis

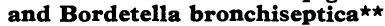

\begin{tabular}{|c|c|c|c|c|c|c|c|c|}
\hline \multirow{3}{*}{\multicolumn{2}{|c|}{$\begin{array}{c}\text { Piglets } \\
\text { No. }\end{array}$}} & \multirow{4}{*}{$\begin{array}{c}\begin{array}{c}\text { Days after } \\
\text { infection } \\
\text { when killed }\end{array} \\
\\
21 \\
21 \\
42\end{array}$} & \multicolumn{2}{|c|}{ Gross changes } & \multicolumn{4}{|c|}{ Isolations } \\
\hline & & & \multirow{2}{*}{ in turbinates } & \multirow{2}{*}{ in lungs } & \multicolumn{2}{|c|}{$\begin{array}{l}\text { M. hyorhinis } \\
\text { from tur- }\end{array}$} & \multicolumn{2}{|c|}{$\begin{array}{l}\text { B. bronchiseptica } \\
\text { from tur- }\end{array}$} \\
\hline & & & & & $\begin{array}{l}\text { binate } \\
\text { mucosa }\end{array}$ & $\begin{array}{l}\text { from } \\
\text { lung }\end{array}$ & $\begin{array}{l}\text { binate } \\
\text { mucosa }\end{array}$ & $\begin{array}{l}\text { from } \\
\text { lung }\end{array}$ \\
\hline 营 & $\begin{array}{ll}K & 11 \\
K & 12 \\
K & 13\end{array}$ & & $\begin{array}{l}1 \\
3 \\
2\end{array}$ & $\begin{array}{l}\overline{2} \\
2\end{array}$ & $\begin{array}{l}+\left(10^{1}\right)^{* * *} \\
+\left(10^{1}\right) \\
+\left(10^{2}\right)\end{array}$ & $\begin{array}{l}+\left(10^{2}\right) \\
+\left(10^{8}\right)\end{array}$ & $\begin{array}{l}3 \\
4 \\
4\end{array}$ & $\overline{3}$ \\
\hline 总焉焉 & $\begin{array}{rr}\mathrm{K} & 9 \\
\mathrm{~K} & \mathbf{1 0} \\
\mathrm{K} & 8\end{array}$ & $\begin{array}{l}21 \\
21 \\
42\end{array}$ & $\frac{2}{3}$ & $=$ & $\begin{array}{l}+\left(10^{1}\right) \\
+\left(10^{1}\right) \\
+\left(10^{2}\right)\end{array}$ & $\begin{array}{l}\overline{-}\left(10^{2}\right) \\
+\left(10^{3}\right)\end{array}$ & $\frac{3}{-}$ & $\begin{array}{l}- \\
-\end{array}$ \\
\hline
\end{tabular}

* Infecting inoculum titre of $4.0 \times 10^{8} \mathrm{CFU} / \mathrm{ml}$

** Infecting inoculum titre of $7.0 \times 10^{8} \mathrm{CFU} / \mathrm{ml}$

*** Colour-changing units 
findings in the nasal cavities and lungs (Table 2) did not suggest a higher protection of the lung against microbial invasion in immunized piglets than in the controls when a relatively high challenge level was employed.

In the group of piglets challenged with the highest dose of $B$. bronchiseptica, $5.0 \times 10^{9} \mathrm{CFU} / \mathrm{ml}$, the 5 controls all had marked turbinate atrophy and 4 of them had also extensive lesions in the lung. Of the 5 immunized piglets, 3 showed marked atrophy and 4 had lung lesions, mainly of grade 3. Microbiological findings correlated with the gross changes (Table 3). High infecting doses produced extensive lesions in the nasal cavities and lungs, no matter whether the piglets were immunized or not.

These findings in these experiments on gnotobiotic piglets suggest that the extent of pathological changes in the nasal cavities and lungs was related to the size of the infecting dose. This would imply that hyperimmune serum is able to restrict the development of pathological changes only if the infection is not massive.

In another similar experiment, the protective effect of bivalent hyperimmune serum against $B$. bronchiseptica and $M$. hyorhinis was tested on three conventional piglets. These were infected with $2.0 \times 10^{8} \mathrm{CFU} / \mathrm{ml}$ of strain of $M$. hyorhinis $\mathrm{S} 218$ at 5 days of age and with $7.0 \times 10^{8} \mathrm{CFU} / \mathrm{ml}$ of the $B$. bronchiseptica strain 48 hours later. Macroscopic changes in the turbinates and lungs were more frequent in the controls than in the immunized animals. The same applies to the frequency of isolation of the two organisms (Table 4). This would indicate that bivalent serum may restrict the extent of pathological changes in the respiratory tract, even in combined infections.

\section{Active Immunization of Piglets Against B. bronchiseptica Intraperitoneal Immunization}

The experiment involved 12 piglets from a sow from a minimum-disease herd. Six of them were immunized i. p. and six served as controls. All were exposed to infection at 20 days of age, i. e. immediately after the second vaccination of the experimental animals, by placing them in contact with two gnotobiotic piglets that had been infected with $B$. bronchiseptica in incubators. During the next 21 days the contact piglets were examined several times for the presence of $B$. bronchiseptica in the nasal cavities by means of nasal swabs. The results of these examinations, together with the numbers of the organisms in the nasal cavities determined after slaughter (32 days after contact infection) and the macroscopic findings in the nasal cavities, suggest that i. $p$. vaccination may give piglets a moderate degree of protection. Of the 6 vaccinated piglets, 2 had normal turbinates, three showed turbinate atrophy of grade 1 and one had turbinate atrophy of grade 2. The six controls all had turbinate atrophy and some had also deviation of the nasal septum; these pathological changes were of grade 1 in two animals, grade 2 in three and grade 3 in one animal. The numbers of $B$. bronchiseptica organisms colonizing the nasal cavities were generally higher in non-vaccinated than in vaccinated piglets as shown by the results of examinations made during the experiment and after sacrifice (Table 5). The results suggest that vaccination gave the piglets only a partial protection against massive colonization by $B$. bronchiseptica and apparently protected them also from the development of marked turbinate atrophy. The sera obtained from the vaccinated piglets at sacrifice all contained low levels of agglutinating antibody $(1: 10$ to $1: 20)$, whereas the controls had a titre of $1: 10$ only in one animal and negative results $(1: 5)$ in the others. 
In other experiments, the effect of i. p. immunization was tested in small groups of gnotobiotic and conventional piglets which, unlike those in the previous experiment, were infected intranasally with $B$. bronchiseptica at a rate of about $10^{10}$ $\mathrm{CFU} / \mathrm{ml}$. When the animals were killed 21 days after infection, no differences were found in the degree of turbinate atrophy and microbiological findings between vaccinated and non-vaccinated animals. The degree of protection that can be conferred to piglets by this form of immunization is open to question.

Table 5

Intraperitoneal vaccination against Bordetella bronchiseptica of piglets from a herd with minimal morbidity

\begin{tabular}{|c|c|c|c|c|c|c|c|c|c|c|c|c|}
\hline \multirow{2}{*}{$\begin{array}{l}\text { Piglet } \\
\text { No. }\end{array}$} & \multicolumn{6}{|c|}{ Vaccinated } & \multicolumn{6}{|c|}{ Non-vaccinated } \\
\hline & 33 & 34 & 36 & 42 & 43 & 44 & 35 & 37 & 38 & 39 & 40 & 41 \\
\hline \multirow{9}{*}{$\begin{array}{l}\text { Vaccinated at } \\
12 \text { days of age } \\
\text { Revaccinated at } \\
20 \text { days of age } \\
\text { Infected by contant } \\
\text { after revaccination } \\
\text { Finding of } B \text {. } \\
\text { bronchiseptica } \\
\text { in nasal } \\
\text { cavities; figures } \\
\text { in parentheses } \\
\text { denote number } \\
\text { of days after } \\
\text { exposure to } \\
\text { infection } \\
\end{array}$} & 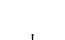 & 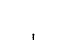 & 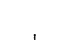 & 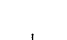 & 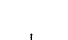 & t & & 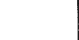 & 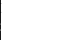 & & 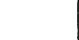 & \\
\hline & + & + & t & t & t & 1 & - & - & 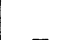 & 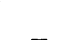 & 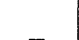 & $\pi$ \\
\hline & + & $T^{+}$ & + & $T^{T}$ & $T$ & $T^{+}$ & - & - & - & - & - & - \\
\hline & + & + & + & + & + & + & + & + & + & + & + & + \\
\hline & 4 & 2 & 3 & - & 2 & 2 & 2 & - & 3 & 3 & 3 & 2 \\
\hline & 4 & 3 & 3 & 1 & 3 & 4 & 4 & 4 & 4 & 4 & 1 & 3 \\
\hline & 3 & 3 & 2 & 1 & 3 & 4 & 3 & 3 & 4 & 2 & 3 & 3 \\
\hline & 2 & 2 & 2 & 3 & 3 & 4 & 2 & 4 & 4 & 4 & 4 & 4 \\
\hline & 1 & 2 & 2 & 2 & 2 & 4 & 3 & 3 & 2 & 2 & 4 & 4 \\
\hline $\begin{array}{l}\text { Days after exposure } \\
\text { when killed }\end{array}$ & 32 & 32 & 32 & 32 & 32 & 32 & 32 & 32 & 32 & 32 & 32 & 32 \\
\hline \multirow{3}{*}{$\begin{array}{l}\text { Gross findings in } \\
\text { turbinates and nasal } \\
\text { septum } \\
\text { Bacteriological } \\
\text { findings in turbinates } \\
\text { Titre of } \\
\text { agglutinating } \\
\text { antibodies }\end{array}$} & 1 & 2 & - & 1 & 1 & - & 1 & 2 & 1 & 3 & 2 & 2 \\
\hline & - & 2 & 2 & 2 & 2 & 3 & 3 & 3 & 2 & 2 & 4 & 3 \\
\hline & $1: 20$ & $1: 20$ & $1: 10$ & $1: 20$ & $1: 20$ & $1: 20$ & $1: 10$ & $1:<5$ & $1:<5$ & $1:<5$ & $1:<5$ & $1:<5$ \\
\hline
\end{tabular}

\section{Inoculation into the Nasal Submucosa}

The experiment involved 8 conventional piglets, half of which were vaccinated as described in Materials and Methods. They, and the controls, were challenged with $B$. bronchiseptica at a rate of $3.0 \times 10^{8} \mathrm{CFU} / \mathrm{ml}$. As in the previous group, a slight difference between vaccinated and non-vaccinated animals was apparent: of the 4 vaccinated piglets, 1 had turbinate atrophy and 2 had solitary colonies of $B$. bronchiseptica at the affected sites, whereas in the control group 2 animals showed slight turbinate atrophy alone or in combination with deviation of the nasal septum and massive colonization of the turbinate mucosa by $B$. bronchiseptica (Table 6). This slight difference between vaccinated piglets and controls cannot be interpreted as indicating the merits of vaccination, since the number of animals employed was too small. On the other hand, it is evident that the vaccine administered by this route stimulated the production of agglutinating antibodies in the serum (Table 6). 
Table 6

Vaccination against Bordetella bronchiseptica of conventional piglets by inoculation into the nasal submucosa

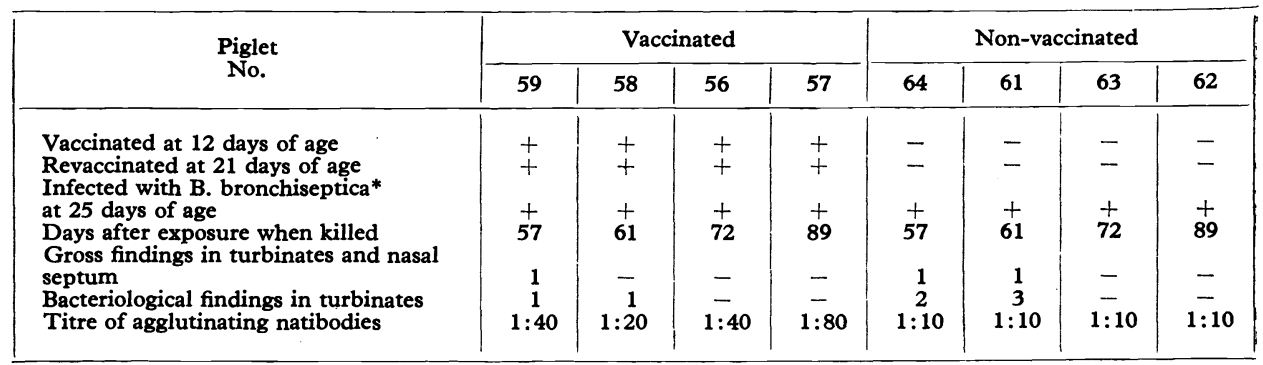

* Infecting inoculum titre of $2.0 \times 10^{\circ} \mathrm{CFU} / \mathrm{ml}$

Table 7

Subcutaneous vaccination against Bordetella bronchiseptica of conventional piglets by inoculation in the axillary and inguinal regions

\begin{tabular}{|c|c|c|c|c|c|c|c|c|c|c|c|c|}
\hline \multirow{2}{*}{$\begin{array}{l}\text { Piglet } \\
\text { No. }\end{array}$} & \multicolumn{6}{|c|}{ Vaccinated } & \multicolumn{6}{|c|}{ Non-vaccinated } \\
\hline & 86 & 88 & 93 & 94 & 95 & 87 & 90 & 91 & 96 & 97 & 98 & 89 \\
\hline \multirow{9}{*}{$\begin{array}{l}\text { Vaccinated at } \\
12 \text { days of age } \\
\text { Revaccinated at } \\
19 \text { days of age } \\
\text { Infected with } \\
\text { B. bronchiseptica* } \\
\text { at } 26 \text { days of age } \\
\text { Days after exposure } \\
\text { when killed } \\
\text { Gross findings in } \\
\text { turbinates and nasal } \\
\text { septum } \\
\text { Bacteriological } \\
\text { findings in turbinates } \\
\text { Titre of aggluti- } \\
\text { nating antibodies }\end{array}$} & & & & & & & & & & & & \\
\hline & + & + & + & + & + & + & - & - & - & - & - & - \\
\hline & + & + & + & + & + & + & - & - & - & - & - & - \\
\hline & + & + & + & + & + & + & + & + & + & + & + & + \\
\hline & 30 & 44 & 60 & 60 & 71 & 71 & 30 & 44 & 60 & 60 & 71 & 71 \\
\hline & & & & & & & & & & & & \\
\hline & - & - & - & - & - & - & - &. & 1 & - & 2 & 1 \\
\hline & 2 & - & 1 & 1 & 1 & - & 4 & 1 & 1 & 2 & 3 & 2 \\
\hline & $1: 10$ & $1: 40$ & $1: 40$ & $1: 40$ & $1: 80$ & $1: 320$ & $1:<5$ & $1: 10$ & $1: 10$ & $1: 10$ & $1: 10$ & $1: 10$ \\
\hline
\end{tabular}

* Infecting inoculum titre of $3.0 \times 10^{10} \mathrm{CFU} / \mathrm{ml}$

\section{Subcutaneous Vaccination}

The experiment involved 12 piglets, half of which were vaccinated as described in Materials and Methods. The infecting dose contained $2.0 \times 10^{9} \mathrm{CFU} / \mathrm{ml}$. The result suggest that $\mathrm{s}$. c. vaccination gave the piglets local protection against the development of turbinate atrophy and deviation of the nasal septum. The 6 vaccinated piglets all had normal turbinates, whereas 3 of the 6 controls showed slight to moderate turbinate atrophy and deviation. In agreement with these results, microbiological examination revealed $B$. bronchiseptica more frequently and in higher concentrations in the nasal cavities of the controls than in the vaccinated animals (Table 7). Comparison of the titres of agglutinating antibodies in the two groups shows that s. c. immunization stimulated the production of serum antibodies. 


\section{Discussion}

In agreement with other studies (Harris and Switzer 1972; Farrington 1974; Nakase et al. 1976) double s. c. vaccination of piglets was effective in restricting the development of pathological changes due to $B$. bronchiseptica. Inoculation into the nasal submucosa and i. p. immunization, on the other hand, proved to be only a mildly stimulating means of restricting the growth of $B$. bronchiseptica and the development of pathological changes. However, it should be pointed out that the numbers of animals employed were too small to permit more definite conclusions as to the effects of the individual immunization procedures. Since s. c. vaccination showed the most promise, trials were started to test its effect on a larger scale in herds with a history of AR and B. bronchiseptica infection.

Our experiments with administration of hyperimmune sera were guided by the observations that colostral antibodies may protect piglets from the development of atrophic changes fairly well provided that the infecting doses of $B$. bronchiseptica are not too high (Koshimizu et al. 1973). The protective efficacy of the hyperimmune serum decreases with increasing infecting dose. In the present study, piglets infected with relatively large doses of $B$. bronchiseptica had more severe changes in the nasal cavities and lungs than animals infected with the lower doses. Nevertheless, the evidence from the present experiments suggests that antibodies administered i. p. reach not only the lower, but also the upper respiratory tract in such concentrations that their direct or indirect effects increase the body defences of the animal. Similar results were obtained in our previous experiments on gnotobiotic piglets infected with M. hyorhinis (Goiš et al. 1974). The results reported here warrant further trials of specific serotherapy and seroprophylaxis in infectious diseases of the respiratory tract. Similarly, the evidence from experiments with other microorganisms such as Pasteurella multocida (Collins 1973), Vibrio cholerae (Pike and Chandler 1971), Mycoplasma hyopneumoniae (Lam and Switzer 1971) and Mycoplasma pulmonis (Taylor and Taylor-Robins on 1976) suggests that the colonizing activity and growth of the organisms were markedly restricted by passively administered specific antiserum. All this implies that specific antisera may find general application in the treatment or prophylaxis of bacterial infection.

Our field trials with immunoprophylaxis of AR are still in progress. The results so far have failed to provide convincing evidence. In some herds, vaccination in combination with sanitary measures reduced the incidence of $B$. bronchiseptica and AR (Goiš et al. 1978) but failed to do so in others. This would imply that more than one agent is involved in the aetiology of AR. Nevertheless, vaccination against $B$. bronchiseptica may prove useful as part of AR control measures in the field.

\section{Pasivní a aktivní ochrana před vývojem změn u selat infikovaných Bordetella bronchiseptica}

V práci byly prokázány účinky aktivní a pasivní imunizace na omezení vývoje makroskopických změn na nosních konchách a $\mathrm{v}$ plicích po intranazální nebo kontaktní infekci Bordetella bronchiseptica (B. b.). Účinek specifického hyperimunního séra proti $\mathrm{B}$. b. zkoušený na gnotobiotických selatech, byl ověřován v závislosti na koncentraci intranazálně podaných mikroorganismů. Při infekční dávce $10^{5} \mathrm{kfj}$ B. b. žádné ze šesti selat $(0 / 6)$ ošetřených sérem nevyvinulo změny 
na konchách, naopak u kontrol 6/7. Při infekční dávce $10^{7} \mathrm{kfj}$ mělo $2 / 5$ selat ošetřených sérem změny na konchách a $1 / 5$ na plicích, u kontrol $4 / 4$ na konchách a $2 / 4$ na plicích. Při infekční dávce $10^{9} \mathrm{kfj}$ mělo $3 / 5$ selat ošetřených sérem změny na konchách a 4/5 na plicích, u kontrol 5/5 mělo změny na konchách a 4/5 na plicích.

Účinek opakované intraperitoneální vakcinace usmrcenou kulturou B. b., ověřovaný na selatech $\mathrm{s}$ minimální nemocností nebyl přesvědčivý: $4 / 6$ vakcinovaných vyvinulo změny na konchách proti $6 / 6$ u kontrolních. Při opakované vakcinaci pod sliznici nosních dutin konvenčních selat mělo 1/4 mírné změny na konchách a 2/4 u kontrol. Při opakované podkožní vakcinaci konvenčních selat $0 / 6$ mělo změny na konchách, kdežto $3 / 6$ u kontrol.

Množství zjištovaných mikroorganismů B. b. na sliznici konch, případně $\mathrm{v}$ plicích bylo u kontrol většinou vyšší než u aktivně a pasivně imunizovaných. U aktivně imunizovaných zviřat i. peritoneálně, podslizničně a podkožně došlo $\mathrm{k}$ vytvoření specifických aglutinačních protilátek.

\section{Пассивная и активная защита от изменений, протекающих у свинок, инфи- цированных Bordetella bronchiseptica}

В работе были выявлены последствия активной и пассивной иммунизаций, направленных на ограничение развития макроскопических изменений носовых раковин и легких после интраназальной или контактной инфекций Bordetella bronchiseptica (B. b.). Воздействие специфической гипериммунной сыворотки против В. b. проверяемое на гнотобиотических свинках, исследовалось в зависимости от концентрации интраназально подаваемых микроорганизмов. При инфекционной дозе $10^{5}$ кфе В. b., ни на одной из шести свинок $(0 / 6)$, которым вводилась сыворотка, не неблюдались изменения на носовых раковина, наоборот у контрольных - 6/7. При инфекционной дозе $10^{7}$ кфе $2 / 5$ свинок, получающих сыворотку, проделали изменения раковин и $1 / 5$ свинок - легких, контрольные - 4/4 раковин и $2 / 4$ легких. При инфекционной дозе $10^{9}$ кфе у $3 / 5$ свинок, получающих сыворотку, наблюдались изменения раковин и $4 / 5$ - на легких, у контрольных $5 / 5$ отличалось изменениями раковин и $4 / 5$ легких.

При повторной внутрибрюшинной вакцинации умерщвленной культуры B. b. проверяемое на свинках с минимальной заболеваемостью воздействие не было убедительным: у 4/6 вакцинированных наблюдались изменения раковин по сравнению с 6/6 у контрольных. При повторной вакцинации под слизистой полостей носа исследуемых свинок наблюдались у $1 / 4$ незначительные изменения раковин и $2 / 4$ у контрольных. При повторной подкожной вакцинации исследуемых свинок $0 / 6$ отличалось изменениями раковин, однако, $3 / 6$ у контрольных.

Количество выявляемых микроорганизмов В. b. на слизистых раковин или в легких было у контрольных групп зачастую выше по сравнению с активно или пассивно иммунизированными. У активно интерперитонеально, подслизисто или подкожно иммунизированных животных наблюдалось образование специфических агглютинационных антител.

\section{References}

BRASSINE, M. - DEWAELE, A. - GOURFAUX, M.: Intranasal infection with Bordetella bronchiseptica in gnotobiotic piglets. Res. Vet. Soc., 20, 1976: 162-166.

COLLINS, F. M.: Growth of Pasteurella multocida in vaccinated and normal mice. Infect. Immun. 8, 1973; 868-875. 
DIRKS, C. - SCHOESS, P. - SCHIMMELPFENNIG, H.: Untersuchungen zur Atiologie der Rhinitis atrophicans des Schweines. Dtsch. tierärztl. Wschr., 79, 1973; 341-347.

EDINGTON, N. - SMITH, I. M. - PLOWRIGHT, W. - WATT, R. G.: Relationship of porcine cytomegalovirus and B. bronchiseptica to atrophic rhinitis in gnotobiotic piglets Vet. Rec., 98, 1976: 42-45.

FARRINGTON, D. O.: Evaluation of nasal culturing procedures and immunization as applied to the control of Bordetella bronchiseptica rhinitis in swine. Diss. Abstr. Int., 35, 1974: 589-590.

GOIS, M. - KUKSA, F. - FRANZ, J.: Influence of intraperitoneal administration of hyperimmune pig serum IgG and IgM on the development of infection in gnotobiotic piglets infected intranasally with Mycoplasma hyorhinis. Zbl. VetMed., 21, 1974: 176-187.

GOIS, M. - KUKSA, F. - ŚIŚÁK, F.: Experimental infection of gnotobiotic piglets with Mycoplasma hyorhinis and Bordetella bronchiseptica. Zbl. VetMed., 24, 1977: 89-96.

GOIŠ, M. - ŠIŚ́K, F. - KUKSA, F. - SOVADINA, M.: Incidence and evaluation of the microbial flora in the lungs of pigs with enzootic pneumonia. Zbl. VetMed., 22, 1975: 205-219.

GOIŠ, M. - SIŚÁK, F. - KUKSA, F. - MESÁROŠ, E.: Vliv hygienickoorganizačních opatření a vakcinace proti Bordetella bronchiseptica na tlumení sípavky prasat. Veterinár̆ství, 28, 1978: $538-540$.

GWATKIN, R. - DZENIS, L. - BYRNE, J. L.: Rhinitis of swine. VII. Production of lesions in pigs and rabbits with a pure culture of Pasteurella multocida. Can. J. comp. Med., 17, 1953: $215-217$.

HARRIS, D. L. - SWITZER, W. P.: Turbinate atrophy in young pigs exposed to Bordetella bronchiseptica, Pasteurella multocida, and combined inoculum. Am. J. Vet. Res., 29, 1968: $777-785$.

HARRIS, D. L. - SWITZER, W. P.: Immunization of pigs against Bordetella bronchiseptica infection by parenteral vaccination. Am. J. vet. Res., 33, 1972: 1976-1984.

deJONG, M. F. - BERCOVICH, L. - AKKERMANS, J. P. W. M.: Atrophic rhinitis control in the Netherlands. Proc. Int. Pig. Vet. Soc., 1976: P. 5-6.

KEMENY, L. J.: Experimental atrophic rhinitis produced by Bordetella bronchiseptica culture in young pigs. Cornell Vet., 62, 1972: 477-485.

KEMENY, L. J.: Agglutinin response of pigs to intranasal infection of Bordetella bronchiseptica. Cornell Vet., 63, 1973: 130-137.

KOSHIMIZU, K. - KODAMA, J. - OGATA, M. - KEMO, T. - SANDYAKUDA S. -

MIMURA, T. : Studies on the etiology of infectious atrophic rhinitis of swine. VI. Effect of vaccination against nasal establishment of Bordetella bronchiseptica. Jap. J. vet. Sci., 35, 1973: $411-418$.

LAM, K. M. - SWITZER, W. P.: Mycoplasmal pneumonia of swine. Active and passive immunization. Am. J. vet. Res., 32, 1971: 1737-1741.

LOGOMARSINO, J. V. - POND, W. G. - SHEFFY, B. E. - KROOK, L.: Turbinate morphology in pigs inoculated with Bordetella bronchiseptica and fed high or low calcium diets. Cornell Vet., 64, 1974: 573-583.

NAKAGAWA, M. - SCHMITZU, T. - MOTOI, Y.: Pathology of experimental atrophic rhinitis in swine infected with Alcaligenes bronchisepticus or Pasteurella multocida. Nat. Inst. An. Hlth Quart., 14, 1974: 61-71.

NAKASE, Y. - KIMURA, M. - SHIMODA, K.: Efficacy of an inactivated Bordetella bronchiseptica vaccine for atrophic rhinitis under field condition. Proc. Int. Pig Vet. Soc., 1976: P. 8.

NIELSEN, N. C. - RUSING, H. J. - BILLE, N.: Experimental reproduction of atrophic rhinitis in pigs reared to slaughter weight. Proc. Int. Pig Vet. Soc., 1976: P. 1,

PIKE, R. M. - CHANDLER, C. H.: Passive protection of mice against intraperitoneally infected Vibrio cholerae by $G$ and $M$ antibody. Inf. Immun., 4, 1971: 589-592.

PURCELL, R. H. - TAYLOR-ROBINSON, D. - CHANOCK, R. M.: Colour test for the measurement of antibody to T-strain mycoplasmas. J. Bact., 92, 1966: 6-11.

ROSS, R. F. - DUNCAN, J. R. - ROBERTS, J.: Comparison of pathogenicity of various isolates of Bordetella bronchiseptica in young pigs. Can J. comp. Med., 31, 1967: 53-57.

SCHIMIZU, T. - NAGAKAWA, M. - SHIBATA, S. - SUZUKI, K.: Atrophic rhinitis produced by intranasal inoculation of Bordetella bronchiseptica in hysterectomy-produced colostrum-deprived pig. Cornell Vet., 61, 1971: 696-705.

TAYLOR, G. - TAYLOR-ROBINSON, D.: Effect of active and passive immunization on Mycoplasma pulmonis-induced pneumonia in mice. Immunology, 30, 1976: 611-618.

TORNØE, N. - NIELSEN, N. C.: Inoculation experiments with Bordetella bronchiseptica strains in SPF pigs. Nord. VetMed., 28, 1976: 233-242. 